\title{
Ultrastructure and gliding motility of Mycoplasma amphoriforme, a possible human respiratory pathogen
}

Correspondence

Mitchell F. Balish

BalishMF@MUOhio.edu

Received 8 February 2006

Revised 23 March 2006

Accepted 10 April 2006

\author{
Jennifer M. Hatchel, ${ }^{1}$ Rebecca S. Balish, ${ }^{1}$ Matthew L. Duley ${ }^{2}$ \\ and Mitchell F. Balish ${ }^{1}$ \\ Department of Microbiology ${ }^{1}$ and Department of Zoology and Miami University Electron \\ Microscopy Facility2, Miami University, Oxford, $\mathrm{OH}$ 45056, USA
}

\begin{abstract}
Despite their small size and reduced genomes, many mycoplasma cells have complex structures involved in virulence. Mycoplasma pneumoniae has served as a model for the study of virulence factors of a variety of mycoplasma species that cause disease in humans and animals. These cells feature an attachment organelle, which mediates cytadherence and gliding motility and is required for virulence. An essential component of the architecture of the attachment organelle is an internal detergent-insoluble structure, the electron-dense core. Little information is known regarding its underlying mechanisms. Mycoplasma amphoriforme, a close relative of both M. pneumoniae and the avian pathogen Mycoplasma gallisepticum, is a recently discovered organism associated with chronic bronchitis in immunosuppressed individuals. This work describes both the ultrastructure of $M$. amphoriforme strain $\mathrm{A}_{3} 9^{\top}$ as visualized by scanning electron microscopy and the gliding motility characteristics of this organism on glass. Though externally resembling M. gallisepticum, M. amphoriforme cells were found to have a Triton X-100-insoluble structure similar to the $M$. pneumoniae electron-dense core but with different dimensions. M. amphoriforme also exhibited gliding motility using time-lapse microcinematography; its movement was slower than that of either M. pneumoniae or M. gallisepticum.
\end{abstract}

\section{INTRODUCTION}

Within the genus Mycoplasma of the bacterial class Mollicutes, the pneumoniae group (Johansson \& Pettersson, 2002) consists of numerous species, some commensal and some pathogenic, that live in association with vertebrates, including humans. Mycoplasma amphoriforme is a recently discovered member of the Mycoplasma pneumoniae cluster of the pneumoniae group (Webster et al., 2003); its closest relatives include the avian respiratory pathogen $\mathrm{Myco}$ plasma gallisepticum (Levisohn \& Kleven, 2000), the human respiratory pathogen Mycoplasma pneumoniae (Waites \& Talkington, 2004), and the human urogenital tract pathogen Mycoplasma genitalium (Jensen, 2004). Analysis of $16 S$ rRNA sequence indicates a closer relationship with $M$. gallisepticum than with the others. M. amphoriforme strain $\mathrm{A} 39^{\mathrm{T}}$ was identified as a frequent inhabitant of the respiratory tracts of immunodeficient patients with chronic bronchitis, but not of immunocompetent patients (Webster et al., 2003); it was cultured independently from such patients multiple times (Pitcher et al., 2005). The details of the clinical case presented (Webster et al., 2003) suggest that

Abbreviations: SEM, scanning electron microscopy; TN, Tris- $\mathrm{NaCl}$ buffer; TX, Triton X-100.
M. amphoriforme is an opportunist that is likely pathogenic, especially in immunodeficient individuals.

The species of the M. pneumoniae cluster (Johansson \& Pettersson, 2002) have numerous distinctive morphological features in common, including a flask-shaped appearance with a prosthecal polar structure, usually called the attachment organelle in M. pneumoniae literature and the terminal bleb in M. gallisepticum literature (Kirchhoff et al., 1984; Balish \& Krause, 2002). Best studied in M. pneumoniae, the attachment organelle is the primary site at which the mycoplasma cell attaches (cytadheres) to the host cell using localized adhesin proteins (Feldner et al., 1982; Hu et al., 1982; Baseman et al., 1987; Krause, 1996). The attachment organelle contains an electron-dense core (Biberfeld \& Biberfeld, 1970), which is insoluble in the non-ionic detergent Triton X-100 (TX) (Meng \& Pfister, 1980; Gobel et al., 1981) and regarded as cytoskeletal. M. pneumoniae, M. genitalium and M. gallisepticum also exhibit gliding motility on surfaces (Kirchhoff, 1992); cells invariably glide in the direction of the attachment organelle (Bredt, 1968). Although the mechanism of gliding is not known, loss of virulence due to mutations in the attachment organelle adhesin protein P30 is associated with reduced speed in M. pneumoniae (Hasselbring et al., 2005), suggesting that 
motility is a virulence-associated trait. Duplication of the attachment organelle is also linked with the cell-division process (Bredt, 1968; Seto et al., 2001).

Cytadherence and virulence of M. pneumoniae depend upon a specific set of proteins associated with the attachment organelle, including those required for the presence of the electron-dense core (Balish \& Krause, 2002; Seto \& Miyata, 2003). Although ultrastructural aspects of the $M$. genitalium attachment organelle and the M. gallisepticum terminal bleb are less well-studied, loss of virulence in both species is associated with disruptions to homologues of these M. pneumoniae proteins (Mernaugh et al., 1993; Dhandayuthapani et al., 1999; Papazisi et al., 2002; MudahiOrenstein et al., 2003; May et al., 2006). However, despite the work that has been done in M. pneumoniae, the relationship between the physical features of the attachment organelle and the processes of cytadherence, gliding motility, and attachment organelle duplication and cell division remains obscure.

Since M. amphoriforme is a possible human pathogen whose closest relatives include gliding mycoplasmas that have attachment organelles and associated cytoskeletal structures, we wanted to determine whether M. amphoriforme strain $\mathrm{A} 39^{\mathrm{T}}$ shared these virulence-associated features. We have used scanning electron microscopy (SEM) to investigate the morphological features of $M$. amphoriforme, identifying a probable homologue of the cytoskeleton-like electron-dense core of M. pneumoniae that is distinct from the cytoskeletal structures of M. gallisepticum, despite the external appearance of the cell resembling that of M. gallisepticum much more closely than that of M. pneumoniae. We have also characterized the gliding motility properties of $M$. amphoriforme. The data indicate that $M$. amphoriforme is characterized by a novel combination of morphological features of both M. pneumoniae and M. gallisepticum.

\section{METHODS}

Growth and culture conditions. M. amphoriforme strain $\mathrm{A} 39^{\mathrm{T}}$ (generously provided by J. Jensen, Staatens Serum Institut, Copenhagen, Denmark) was grown in plastic tissue-culture flasks from frozen stocks for $4-6$ days at $37^{\circ} \mathrm{C}$ in SP-4 broth (Tully et al., 1979 ) to mid-exponential phase (phenol red indicator was orange). Cells adhered to the plastic surface of the flask. For motility stocks, cells were prepared according to the method of Hasselbring et al. (2005), with minor modifications. Cells were grown to midexponential phase in $10 \mathrm{ml} \mathrm{SP-4}$ broth. The supernatant was removed and the cells were scraped into $1 \mathrm{ml}$ fresh SP-4 broth. This suspension was then dispensed into $50 \mu \mathrm{l}$ aliquots and stored at $-80{ }^{\circ} \mathrm{C}$. M. pneumoniae strain $\mathrm{M} 129$ and M. gallisepticum strain $\mathrm{R}_{\text {low }}$ (generously provided by $\mathrm{S}$. Geary, University of Connecticut, Storrs, CT, USA) were also cultured at $37^{\circ} \mathrm{C}$ in SP-4 broth, with mid-exponential phase achieved after 2-3 days; motility stocks were prepared as for M. amphoriforme.

Time-lapse microcinematographic analysis. Thirty-fivemicrolitre samples of motility stock were inoculated into $765 \mu \mathrm{l} \mathrm{SP}$ 4 broth supplemented with $3 \%$ gelatin in individual chambers of four-well chamber slides (Nalge Nunc). The suspension was passed seven times through a 25-gauge needle and incubated $3 \mathrm{~h}$ at the appropriate temperature. Cells attached to the slide were visualized using a Leica DM IRB inverted microscope equipped with a $100 \times$ objective. The sample was held at the appropriate temperature (see text) using a heating chamber. Phase-contrast images were captured at fixed intervals using a SPOT charge-coupled device camera and accompanying software (Diagnostic Instruments). Twenty-seven consecutive images were merged in different colour channels using Adobe Photoshop CS version 8.0, enabling visualization of cell movement. The initial image was magenta, the final image was yellow, and the merged image of all 27 frames was cyan. Immotile cells appeared black, whereas motile cells were in colour (see Fig. 5). The distance travelled by each cell corresponds to the length of the cyan line from the tip of the magenta cell to the tip of the yellow cell as measured using the SPOT software. The speed of each cell was computed by dividing the distance travelled by the duration of movement. Cells moving between fewer than 10 of the 27 frames were counted as motile but their speeds were not included in calculations.

SEM. Stocks were inoculated into 24 -well plates containing $1 \mathrm{ml}$ SP-4 broth and glass coverslips coated with $0.01 \%$ poly L-lysine. Cells were grown 1-3 days before processing. For analysis of TXinsoluble structures, coverslips were incubated $30 \mathrm{~min}$ at $37^{\circ} \mathrm{C}$ in a solution containing $2 \% \mathrm{TX}$ in Tris- $\mathrm{NaCl}$ buffer (TN; $20 \mathrm{mM}$ Tris/ $\mathrm{HCl}, \mathrm{pH} 7 \cdot 5 / 150 \mathrm{mM} \mathrm{NaCl}$ ) (Stevens \& Krause, 1991). For analysis of both whole cells and TX-insoluble structures, coverslips were rinsed in $\mathrm{TN}, 4 \times 5 \mathrm{~min}$ and then fixed $30 \mathrm{~min}$ in $1 \%$ glutaraldehyde $/ 2 \%$ formaldehyde $/ 0 \cdot 1 \mathrm{M}$ sodium cacodylate, $\mathrm{pH} 7 \cdot 2$. Coverslips were subsequently rinsed with $0 \cdot 1 \mathrm{M}$ sodium cacodylate, $4 \times 10 \mathrm{~min}$, and dehydrated through a series of ethanol washes from $25 \%$ to $100 \%$. After dehydration, the coverslips were critical-point dried and sputter-coated with $15 \mathrm{~nm}$ gold. Images were viewed and captured at the Electron Microscopy Facility at Miami University on a Zeiss Supra 35 FEG-VP scanning electron microscope operating at $5 \mathrm{kV}$. Dimensions of the TX-insoluble structures were measured using SPOT software.

\section{RESULTS}

\section{The cellular morphology of $M$. amphoriforme is similar to that of $M$. gallisepticum but distinct from M. pneumoniae}

Thin sections of M. amphoriforme observed by transmission electron microscopy suggest a flask-shaped morphology (Webster et al., 2003; Pitcher et al., 2005) consistent with related mycoplasma species of the pneumoniae group (Kirchhoff et al., 1984; del Giudice et al., 1985; Bradbury et al., 1993). SEM of whole M. amphoriforme cells (Fig. 1a, b) confirmed that, like their relatives in the pneumoniae group, they are pleomorphic, with a flask shape. These images also revealed that in many cells the polar extension terminates in a single knob-like structure whose shape is like that of the terminal bleb of M. gallisepticum (Fig. 1c) but distinct from that of the M. pneumoniae attachment organelle (Fig. 1d). M. pneumoniae cells also consistently have a trailing filament (Fig. 1d); this was observed only very rarely in $M$. gallisepticum and M. amphoriforme (data not shown). Some M. amphoriforme cells appeared to be larger, with at least two extensions with knobs at opposite poles (Fig. 2a), closely resembling similar forms reported in M. gallisepticum (Morowitz \& Maniloff, 1966). Others had 
(a)

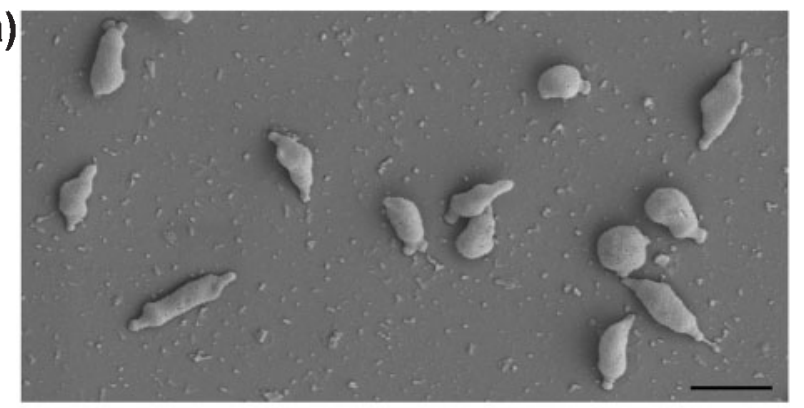

(b)

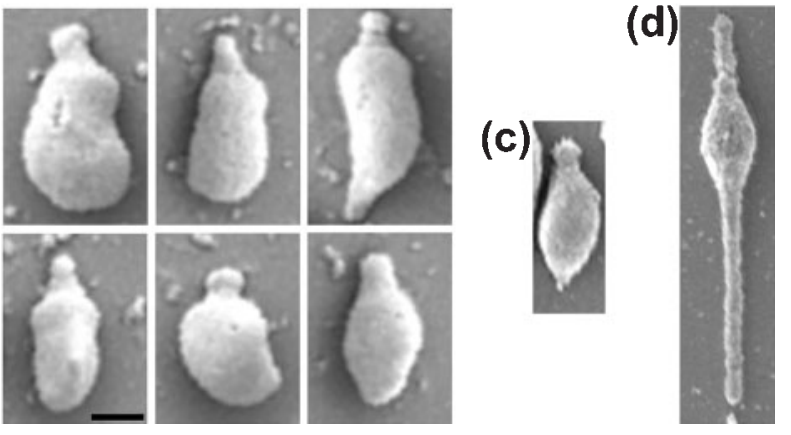

Fig. 1. Scanning electron micrographs of mycoplasma cells grown attached to coverslips. Images of cells are aligned with the attachment-organelle-like structure at the top. (a) $M$. amphoriforme; (b) M. amphoriforme cells with a single polar structure; (c) M. gallisepticum; (d) M. pneumoniae. Scale bar for (a), $1 \mu \mathrm{m}$; scale bar for (b), (c) and (d), $250 \mathrm{~nm}$.

three polar structures (Fig. 2b), and some cells appeared to have a pair of extensions in close proximity at one pole, occasionally with a third extension at the opposite pole (Fig. 2c).

\section{M. amphoriforme has TX-insoluble structures similar to those of $M$. pneumoniae but distinct from M. gallisepticum}

Glass-adherent cells of all three species were extracted in $2 \%$ TX. As observed by SEM, TX-insoluble structures of $M$. amphoriforme that remained adherent to the glass surface following extraction generally resembled those of M. pneumoniae (Fig. 3). These M. amphoriforme structures had elements resembling the terminal button, rod, base and fibres, though each element was larger, more consistently observed and better defined in M. amphoriforme than in M. pneumoniae (Fig. 3a). Fibres extending from the base were found in all M. amphoriforme specimens and exhibited considerable variability in orientation. Baseassociated fibres were only rarely preserved in M. pneumoniae (Fig. 3b). The width of the rod-like portion of the M. amphoriforme TX-insoluble structure was $82 \pm 15 \mathrm{~nm}$ (Table 1), nearly double the width of the $M$. pneumoniae rod. The total length of the rod and the approximately spherical, terminal button-like structure was $254 \pm 20 \mathrm{~nm}$ in M. amphoriforme (Table 1), slightly longer than we measured for M. pneumoniae. The base in the M. amphoriforme

(a)
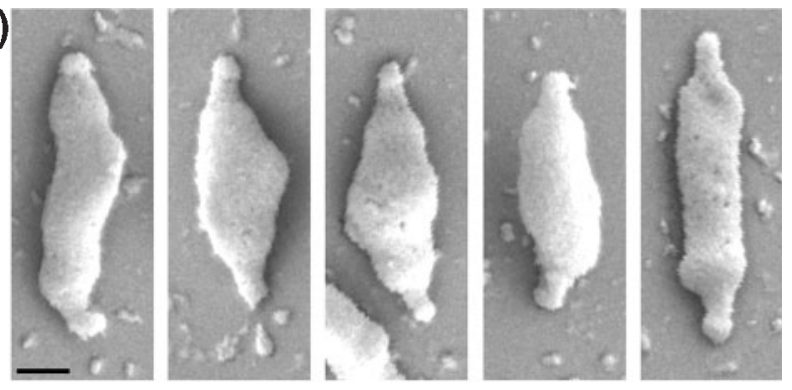

(b)
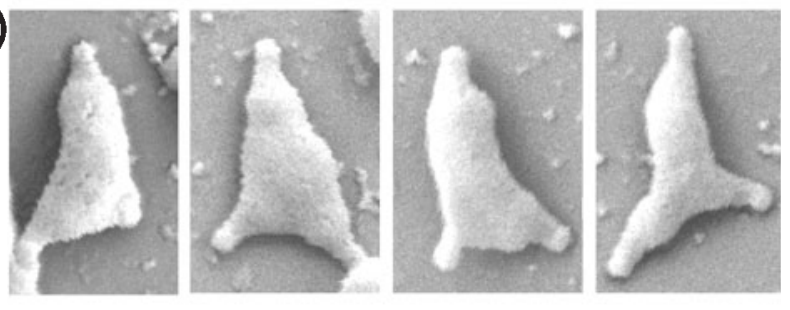

(c)
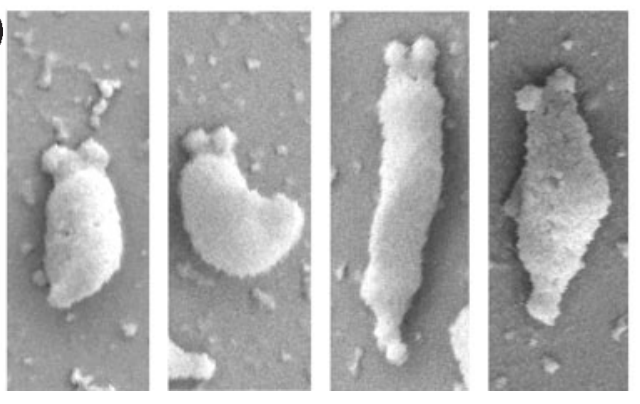

Fig. 2. Scanning electron micrographs of presumptively dividing M. amphoriforme cells grown attached to coverslips. (a) Cells with attachment organelle-like structures at opposite poles; (b) cells with three protrusions roughly equidistant; (c) cells with adjacent protrusions. Scale bar, $250 \mathrm{~nm}$.

structure was irregular but roughly rectangular, $164 \pm$ $16 \mathrm{~nm}$ wide and $90 \pm 16 \mathrm{~nm}$ long (Table 1), substantially larger than that of $M$. pneumoniae (Fig. 3). Despite the close phylogenetic relationship with $M$. amphoriforme and M. pneumoniae, the TX-insoluble fraction of M. gallisepticum was entirely dissimilar, with filamentous or fibrous masses lacking obvious organization and occupying the volume of the entire cell (Fig. 3c).

In M. pneumoniae, the two parallel components of the rod have been observed distinctly only in an hmw 3 mutant (Willby \& Krause, 2002) and in cross-section (Hegermann et al., 2002). In contrast, images of the TX-insoluble structures of $M$. amphoriforme clearly revealed that some rods were approximately doubled in width with a longitudinal cleft, suggestive of a double rod extending from a single base (Fig. 3a, images 4-6). Furthermore, in some cases, the rods were partly (Fig. 3a, image 7 ) or completely (image 8 ) separated, though still apparently extending from a single base, conceivably corresponding to cells with two extensions at a single pole (see Fig. 2c). In M. pneumoniae this cleft was clearly observed only rarely (Fig. 3b, image 7). 
(a)
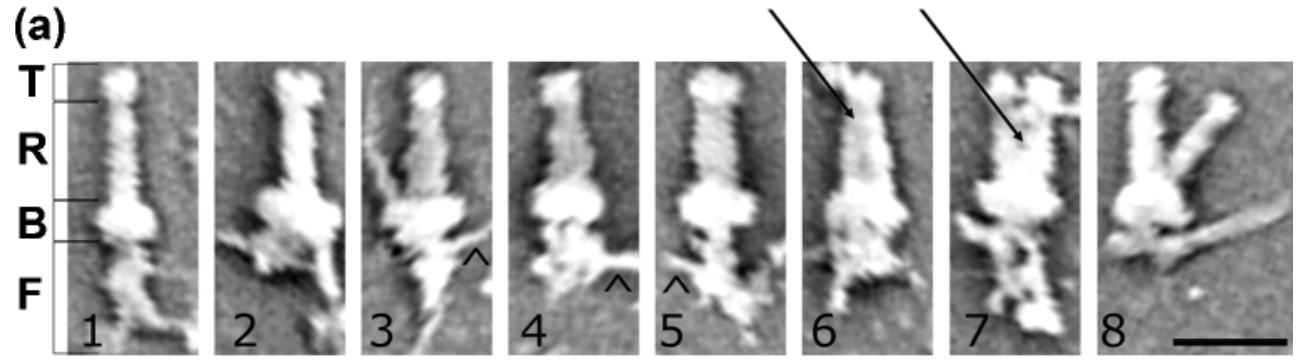

(b)
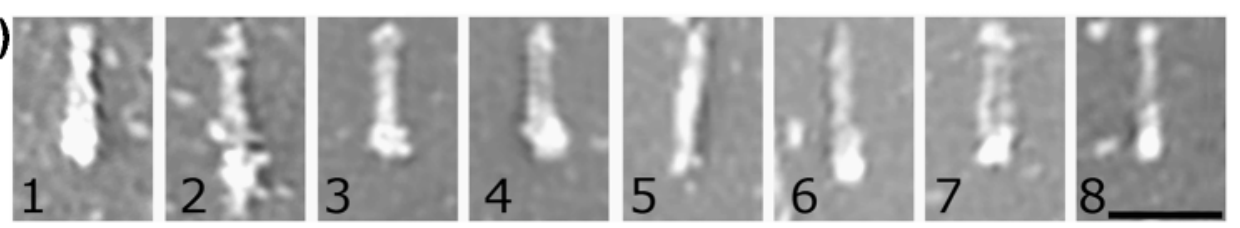

(c)

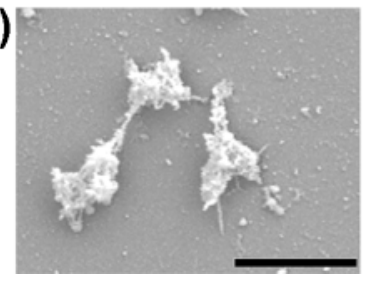

Fig. 3. Scanning electron micrographs of mycoplasma cytoskeletal structures. M. amphoriforme (a), M. pneumoniae (b) and M. gallisepticum (c) cells were grown attached to coverslips and extracted with $2 \%$ TX (see Methods). T, terminal button; R, rod; B, base; F, fibrous extensions. Arrows indicate longitudinal clefts; carets indicate individual fibres. Scale bars: (a) and (b), $250 \mathrm{~nm}$; (c), $1 \mu \mathrm{m}$.

\section{M. amphoriforme cells exhibit slow gliding motility}

Since SEM images indicated that $M$. amphoriforme has a combination of ultrastructural features of $M$. pneumoniae and M. gallisepticum, both of which exhibit gliding

Table 1. Dimensions of the cytoskeleton-like structure of M. amphoriforme and M. pneumoniae

Measurements (in $\mathrm{nm}$, mean $\pm \mathrm{SD}$ ) taken from 29 representative structures for $M$. amphoriforme and 34 representative structures for M. pneumoniae (see Fig. 3). ND, Not determined due to inconsistent resolution of the boundary between the terminal button and the rod.

\begin{tabular}{|lcc|}
\hline & M. amphoriforme & M. pneumoniae \\
\hline Terminal button width & $88 \pm 12$ & $44 \pm 10$ \\
Terminal button length & $73 \pm 12$ & $\mathrm{ND}$ \\
Rod width & $82 \pm 15$ & $45 \pm 8$ \\
Rod length & $181 \pm 17$ & $\mathrm{ND}$ \\
Base width & $164 \pm 16$ & $64 \pm 14$ \\
Base length & $90 \pm 16$ & $56 \pm 14$ \\
(Terminal button + rod) & $254 \pm 20$ & $225 \pm 20$ \\
length & $343 \pm 23$ & $282 \pm 25$ \\
Total length & & \\
\hline
\end{tabular}

${ }^{*}$ Excluding the fibres. motility (Bredt, 1979), we investigated gliding motility in M. amphoriforme. Consecutive phase-contrast images of individual fields revealed that individual $M$. amphoriforme cells glided (Fig. 4). Although the polar protrusion (see Fig. 1) was difficult to see clearly at this resolution, it appeared that cells were moving in the direction of a tapered pole, consistent with this structure (Fig. 4, arrowhead). Cells moved in paths that were clockwise, counterclockwise and approximately straight, and also changed directions (data not shown).

Snapshots of living cells attached to glass under previously established optimal conditions for motility (Hasselbring et al., 2005) were captured at regular intervals; the paths taken by individual cells were characterized with respect to velocity and analysed as a population. We used a merged image of 27 consecutive frames captured at intervals adjusted to ensure that consecutive images of a given cell were overlapping. The false-coloured merged image was overlaid with false-coloured images of the first and last frames in order to indicate unambiguously the starting and stopping points for each cell; as a result, immotile cells were black in the final image, whereas motile ones appeared in colour (see Fig. 5). Finally, the length of the path between the tip of the starting image and the final image was measured.

As a positive control, motility of M. pneumoniae at $37^{\circ} \mathrm{C}$ was measured at intervals of $1 \mathrm{~s}$ at a mean speed of 

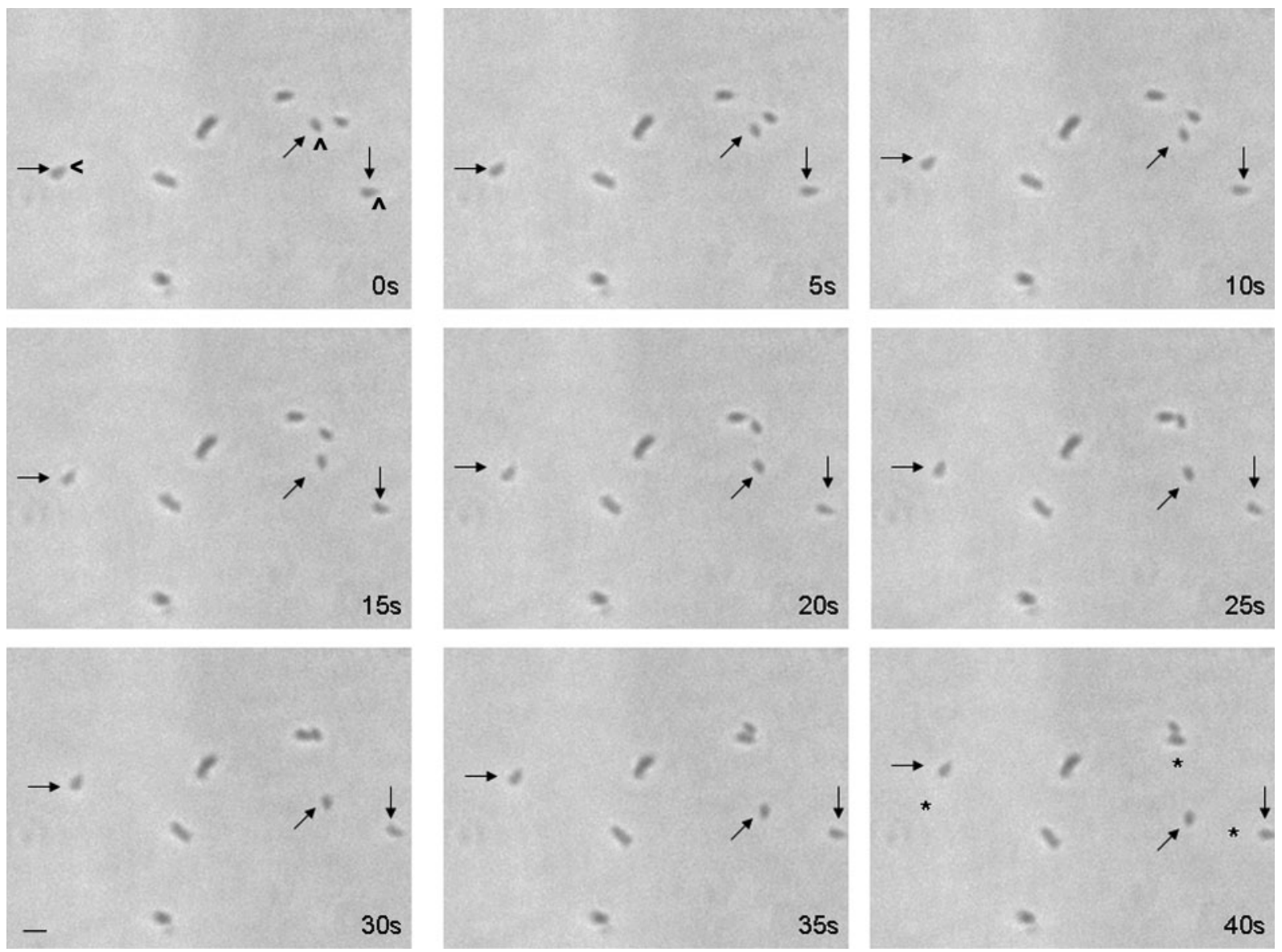

Fig. 4. Consecutive phase-contrast images of $M$. amphoriforme gliding motility at $5 \mathrm{~s}$ intervals at $37^{\circ} \mathrm{C}$. Three representative cells are indicated by arrows orientated horizontally, vertically and diagonally. In the first frame ( $0 \mathrm{~s})$, the carets point to the tapered ends of the indicated cells. In the last frame (40 s), the asterisks indicate the positions of each of the indicated cells at 0 s. Scale bar, $1 \mu \mathrm{m}$.

$336 \pm 59 \mathrm{~nm} \mathrm{~s}^{-1}$ (Table 2), with $51 \%$ of cells gliding at a given time, consistent with previous results (Radestock \& Bredt, 1977; Hasselbring et al., 2005; Seto et al., 2005a). As measured at $37^{\circ} \mathrm{C}$ using $2 \mathrm{~s}$ intervals (Table 2), $M$. gallisepticum strain $\mathrm{R}_{\text {low }}$ glided with a mean speed of $131 \pm 38 \mathrm{~nm} \mathrm{~s}^{-1}$, faster than reported previously for M. gallisepticum (Bredt, 1979), with $64 \%$ gliding at a time. Multiple fields of gliding M. amphoriforme cells were

Table 2. Gliding motility parameters

\begin{tabular}{|c|c|c|c|c|c|c|}
\hline Species & $\begin{array}{l}\text { Total no. } \\
\text { of cells }\end{array}$ & $\begin{array}{c}\text { No. of } \\
\text { motile cells }\end{array}$ & $\begin{array}{l}\text { Percentage of cells } \\
\text { moving per frame } \dagger\end{array}$ & $\begin{array}{c}\text { Mean speed } \\
\left(\mathrm{nm} \mathrm{s} \mathbf{s}^{-1}\right) \ddagger\end{array}$ & $\begin{array}{l}\text { Range of speeds } \\
\qquad\left(\mathrm{nm} \mathbf{s}^{-1}\right)\end{array}$ & $\begin{array}{l}\text { Mean speed of } \\
\text { field }\left(\mathrm{nm} \mathrm{s}^{-1}\right) \S\end{array}$ \\
\hline M. amphoriforme & 1034 & 621 & 53 & $49 \pm 19$ & $15-133$ & $48 \pm 4$ \\
\hline M. pneumoniae & 149 & 80 & 51 & $336 \pm 59$ & $197-538$ & $335 \pm 8$ \\
\hline
\end{tabular}

${ }^{*}$ Total number of motile cells in all fields.

$\dagger$ Because different populations of cells are motile in different frames, the total number of motile cells over an observation period is greater than the total number of motile cells in any one frame.

$¥$ Mean speed of motile cells \pm SD.

$\S$ Mean of mean speeds of motile cells in each field counted \pm SD. 

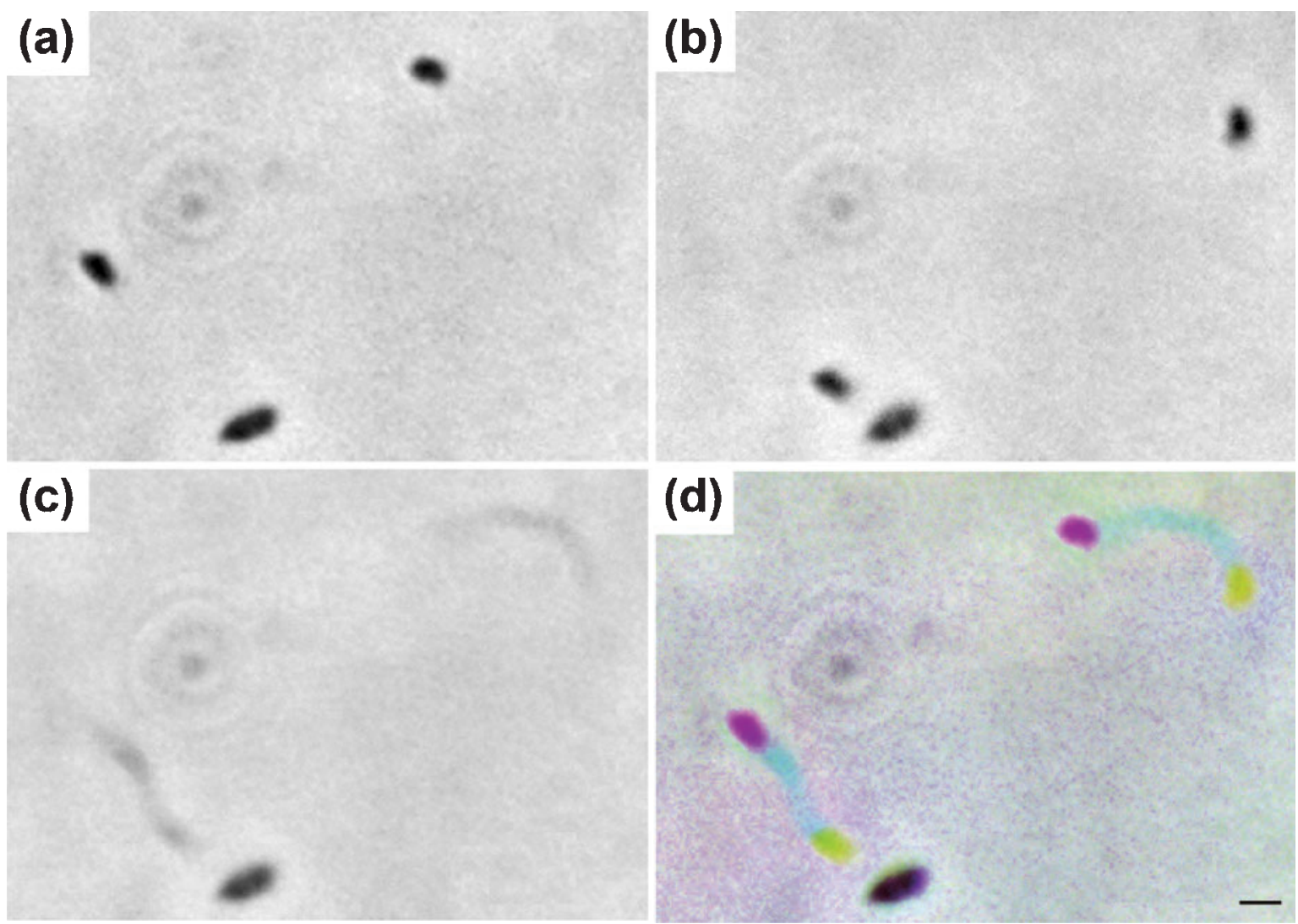

Fig. 5. Measurement of $M$. amphoriforme gliding speed by time-lapse microcinematographic analysis. Phase-contrast images of cells attached to glass slides held at $37^{\circ} \mathrm{C}$ were captured at $5 \mathrm{~s}$ intervals. Twenty-seven consecutive images were merged and the resulting track was measured (see Methods). (a) Image at $0 \mathrm{~s}$; (b) image at $130 \mathrm{~s}$; (c) merged image of all 27 frames between 0 s and $130 \mathrm{~s}$; (d) false-coloured overlay of panels (a) (magenta), (b) (yellow) and (c) (cyan). See Methods for details. For each cell, the distance was measured from the leading end of the magenta image to that of the yellow image along the cyan path, the number of frames in which the cell had moved was determined, and the speed was calculated. Scale bar, $1 \mu \mathrm{m}$.

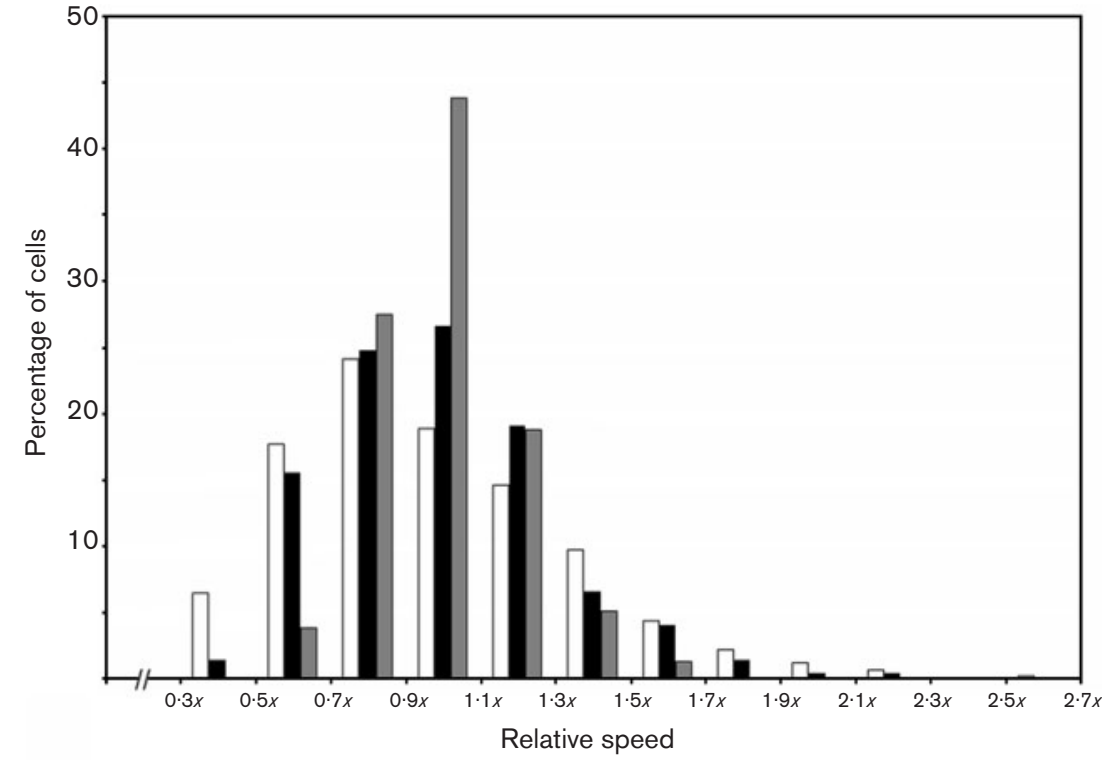

Fig. 6. Distribution of mycoplasma velocities about the mean. Gliding speeds of the individual motile cells for which data are shown in Table 2 were grouped into bins of $0 \cdot 2 \times$ the mean, designated $x$, for each species. The percentage of cells with speeds in a given range out of the total population of motile cells was plotted against the speed as a fraction of the mean speed for each species. White bars, $M$. amphoriforme $(x=49)$; black bars, M. gallisepticum $(x=131)$; grey bars, M. pneumoniae $(x=336)$. 
captured at $5 \mathrm{~s}$ intervals and analysed in this manner (Fig. 5). At $37^{\circ} \mathrm{C}$, M. amphoriforme cells glided at $49 \pm$ $19 \mathrm{~nm} \mathrm{~s}^{-1}$, with $53 \%$ of cells moving at any instant (Table 2). At room temperature M. amphoriforme cells attached poorly and moved more slowly; among those cells that did attach to the glass surface, a substantially smaller fraction was motile (data not shown).

The large standard deviation in the speed of M. pneumoniae (Table 2) was distinct from that reported by previous workers (Hasselbring et al., 2005). However, for each species, gliding rates were unimodal, with a substantial proportion of cells gliding up to twofold faster than the mean speed (Fig. 6). The relatively low standard deviation of mean velocities from field to field for each species (Table 2) indicates that the range of cell velocities is present in each field, as opposed to conditions varying during analysis of each field.

\section{DISCUSSION}

Mycoplasma virulence is multifactorial, with contributions from activities associated with adherence (Balish \& Krause, 2002), competition with host cells for nutrients (Razin et al., 1998), production of harmful molecules such as peroxide (Tryon \& Baseman, 1992), phase variation of surface molecules (Yogev et al., 2002) and motility (Miyata, 2005), in addition to immunopathological factors (Simecka, 2005). The molecular bases for these traits vary among mycoplasma species and are largely not well understood. In the human pathogen M. pneumoniae, molecules and cellular structures associated with cytadherence have been identified, including adhesins and cytadherence accessory proteins, all of which appear to be involved in formation and function of a polar protrusion, the attachment organelle (Krause \& Balish, 2004), which is also instrumental in gliding motility. M. gallisepticum also has such a structure, albeit with a somewhat different appearance, and possesses related molecules, as do other species of the M. pneumoniae cluster (Balish \& Krause, 2005), suggesting that this cluster of related species uses a common set of virulence factors. However, these factors have been well studied only in M. pneumoniae to date, and our understanding of them is limited. Elucidating correlations between attachment organelle-associated characteristics and virulence-associated properties of species other than M. pneumoniae is essential for understanding the common molecular underpinnings of virulence in species of the M. pneumoniae cluster. At the same time, differences identified among these species will underscore specific adaptations of each, casting crucial light on the disease process itself. M. amphoriforme, a likely human pathogen (Webster et al., 2003; Pitcher et al., 2005), is a particularly relevant choice for such studies.

Our results indicate that in contrast to the notion that all of these related mycoplasma species cause disease in essentially the same way at the cellular level, M. amphoriforme has a novel combination of the virulence-associated features of its relatives. M. amphoriforme cells resembled those of M. gallisepticum, not M. pneumoniae, in overall morphology, including the absence of a trailing filament and the presence of a short polar protrusion terminating in a widened knob. In striking contrast, M. amphoriforme cells had discrete TX-insoluble structures with significant resemblance to the M. pneumoniae electron-dense core, which is essential for the architecture and functions of the attachment organelle in cytadherence and gliding motility (Balish \& Krause, 2002). A similar TX-insoluble structure was not distinguishable in M. gallisepticum cells treated in a like manner amidst a remarkably complex mass of material (Fig. 3); extraction with concentrations of TX up to $10 \%$ did not substantially alter the appearance of the fraction (data not shown). These results do not discount the possibility of such an element being present within the M. gallisepticum TX-insoluble fraction, but they demonstrate that a range of ultrastructural complexity not previously anticipated is present among the species of the M. pneumoniae cluster. Although similarities to related species make it likely that the polar structure of $M$. amphoriforme is likely to be involved in infection, its role remains to be determined.

We propose that, as in M. gallisepticum, the polar protrusions observed in M. amphoriforme (Figs 1 and 2) function as sites of attachment, though this remains to be demonstrated formally; however, the contribution to this structure by TX-insoluble cell components is likely to be more similar to M. pneumoniae than to M. gallisepticum. Even so, the M. amphoriforme TX-insoluble structure is nearly twice as wide as and slightly longer than that of M. pneumoniae, with a much more prominent terminal button and base (Fig. 3); this difference in ultrastructure might point towards differences in properties associated with attachment organelle function, though it is not yet possible to propose the specific relationship between structural and functional differences. Like M. pneumoniae, M. amphoriforme has a set of large TX-insoluble proteins (data not shown); future studies will address the identities, locations and cellular roles of these proteins.

Two observations concerning the ultrastructure of the M. amphoriforme TX-insoluble structure relate to proposed roles of the electron-dense core in attachment organelle duplication in M. pneumoniae. First, the M. amphoriforme TX-insoluble structure commonly revealed a cleft within the rod portion (Fig. 3), its visualization perhaps facilitated by the greater width of the rod as compared with $M$. pneumoniae. This cleft might delimit the two parallel elements of the M. pneumoniae core (Hegermann et al., 2002); it also might represent a feature unique to $M$. amphoriforme or, at any rate, one that has not been described in M. pneumoniae. Second, it was possible to see occasional M. amphoriforme images in which a base had two separate and apparently single rods emanating from it (Fig. 3a, images 7 and 8). A possible interpretation of these two observations is that the electron-dense core in 
both $M$. pneumoniae and $M$. amphoriforme consists of a paired rod whose two parallel elements separate longitudinally during attachment organelle duplication, as has been proposed (Krause \& Balish, 2004). Alternatively, the new rod might be synthesized de novo on the same base as the original rod, with division occurring at the base. It is unclear why identical treatment of M. pneumoniae and M. amphoriforme results in differential preservation of these presumably homologous structures; perhaps the interaction between the base and the rod is stronger in $M$. amphoriforme, or this structure might be differentially TX-insoluble in the two species. Regardless, because duplication of attachment organelles and migration to the opposite pole in stages is postulated as the means of M. pneumoniae cell division (Bredt, 1968; Seto et al., 2001), images of relatively large $M$. amphoriforme cells with two or three protrusions (Fig. 2) reinforce the idea that duplication of the organelle and cell division are linked.

In addition to cytadherence and cell division, a third aspect of mycoplasma physiology involving the attachment organelle is gliding motility. In M. pneumoniae as well as in Mycoplasma pulmonis and Mycoplasma mobile, which also exhibit polar protrusions despite lacking homologues of attachment organelle components, the polar structure leads the cell during gliding motility (Miyata, 2005). A handful of novel proteins has been directly implicated in gliding in these species, with an ATP-dependent attach-and-release mechanism suggested (Hasselbring et al., 2005; Seto et al., 2005a, b; Uenoyama \& Miyata, 2005). Despite the fact that the polar structure of $M$. amphoriforme is only marginally resolvable by light microscopy, time-lapse microcinematographic images of glass-adherent $M$. amphoriforme cells suggested that, as in the other species, gliding occurs in the direction of a tapered pole (Fig. 4). However, the mean speed was some sevenfold slower than that of M. pneumoniae and nearly threefold slower than that of M. gallisepticum (Table 2). Neither the molecular basis for gliding motility nor its physiological role is clear, but its conservation in species with different characteristics is further evidence that it is important.

In conclusion, $M$. amphoriforme, a recently discovered likely respiratory pathogen of the immunosuppressed, has virulence-associated ultrastructural features in common with the related species M. pneumoniae and M. gallisepticum. However, these features are present in a unique combination, the overall morphology resembling the latter and the internal structure resembling the former. The dimensions of the M. amphoriforme TX-insoluble structure, which is a probable component of an attachment organelle, differ distinctly from those of the comparable structure in M. pneumoniae. M. amphoriforme also exhibits gliding motility, with a speed that is slower than either of the other species. The presence of distinct varieties and combinations of established virulence characteristics from other species underscores the fact that an understanding of M. amphoriforme-associated disease must derive from direct characterization of this organism, not just from application of information concerning its relatives.

\section{ACKNOWLEDGEMENTS}

This work was supported by startup funds from Miami University. We are grateful to Jorgen Jensen and Steve Geary for supplying mycoplasma strains, to Xiufeng Wan for help with statistical analysis, to Duncan Krause and members of his lab and of the Balish lab for helpful discussions, and to Duncan Krause, Luis Actis and Anne Hooke for help with the manuscript.

\section{REFERENCES}

Balish, M. F. \& Krause, D. C. (2002). Cytadherence and the cytoskeleton. In Molecular Biology and Pathogenicity of the Mycoplasmas, pp. 491-518. Edited by S. Razin \& R. Herrmann. New York: Kluwer Academic/Plenum Publishers.

Balish, M. F. \& Krause, D. C. (2005). Mycoplasma attachment organelle and cell division. In Mycoplasmas: Molecular Biology, Pathogenicity, and Strategies for Control, pp. 189-237. Edited by A. Blanchard \& G. Browning. Norwich, UK: Horizon Bioscience.

Baseman, J. B., Morrison-Plummer, J., Drouillard, D., PuleoScheppke, B., Tryon, V. V. \& Holt, S. C. (1987). Identification of a 32-kilodalton protein of Mycoplasma pneumoniae assocated with hemadsorption. Isr J Med Sci 23, 474-479.

Biberfeld, G. \& Biberfeld, P. (1970). Ultrastructural features of Mycoplasma pneumoniae. J Bacteriol 102, 855-861.

Bradbury, J. M., Abdul-Wahab, O. M., Yavari, C. A., Dupiellet, J. P. \& Bove, J. M. (1993). Mycoplasma imitans sp. nov. is related to Mycoplasma gallisepticum and found in birds. Int J Syst Bacteriol 43, 721-728.

Bredt, W. (1968). Motility and multiplication of Mycoplasma pneumoniae. A phase contrast study. Pathol Microbiol 32, 321-326.

Bredt, W. (1979). Motility. In The Mycoplasmas, vol. 1, pp. 141-155. Edited by M. F. Barile \& S. Razin. Washington, DC: Academic Press.

Del Giudice, R. A., Tully, J. G., Rose, D. L. \& Cole, R. M. (1985). Mycoplasma pirum sp. nov., a terminal structured mollicute from cell cultures. Int J Syst Bacteriol 35, 285-291.

Dhandayuthapani, S., Rasmussen, W. G. \& Baseman, J. B. (1999). Disruption of gene $m g 218$ of Mycoplasma genitalium through homologous recombination leads to an adherence-deficient phenotype. Proc Natl Acad Sci U S A 96, 5227-5232.

Feldner, J., Gobel, U. \& Bredt, W. (1982). Mycoplasma pneumoniae adhesin localized to tip structure by monoclonal antibody. Nature 298, 765-767.

Gobel, U., Speth, V. \& Bredt, W. (1981). Filamentous structures in adherent Mycoplasma pneumoniae cells treated with nonionic detergents. J Cell Biol 91, 537-543.

Hasselbring, B. M., Jordan, J. L. \& Krause, D. C. (2005). Mutant analysis reveals specific requirement for protein P30 in Mycoplasma pneumoniae gliding motility. J Bacteriol 187, 6281-6289.

Hegermann, J., Herrmann, R. \& Mayer, F. (2002). Cytoskeletal elements in the bacterium Mycoplasma pneumoniae. Naturwissenschaften 89, 453-458.

Hu, P. C., Cole, R. M., Huang, Y. S., Graham, T. A., Gardner, D. E., Collier, A. M. \& Clyde, W. A. (1982). Mycoplasma pneumoniae infection: role of a surface protein in the attachment organelle. Science 216, 313-315. 
Jensen, J. S. (2004). Mycoplasma genitalium: the aetiological agent of urethritis and other sexually transmitted diseases. J Eur Acad Dermatol Venereol 18, 1-11.

Johansson, K. E. \& Pettersson, B. (2002). Taxonomy of Mollicutes. In Molecular Biology and Pathogenicity of the Mycoplasmas, pp. 1-29. Edited by S. Razin \& R. Herrmann. New York: Kluwer Academic/ Plenum Publishers.

Kirchhoff, H. (1992). Motility. In Mycoplasmas: Molecular Biology and Pathogenesis, pp. 289-306. Edited by J. Maniloff, R. N. McElhaney, L. R. Finch \& J. B. Baseman. Washington, DC: American Society for Microbiology.

Kirchhoff, H., Rosengarten, R., Lotz, W., Fischer, M. \& Lopatta, D. (1984). Flask-shaped mycoplasmas: properties and pathogenicity for man and animals. Isr J Med Sci 20, 848-853.

Krause, D. C. (1996). Mycoplasma pneumoniae cytadherence: unraveling the tie that binds. Mol Microbiol 20, 247-253.

Krause, D. C. \& Balish, M. F. (2004). Cellular engineering in a minimal microbe: structure and assembly of the terminal organelle of Mycoplasma pneumoniae. Mol Microbiol 51, 917-924.

Levisohn, S. \& Kleven, S. H. (2000). Avian mycoplasmosis (Mycoplasma gallisepticum). Rev Sci Tech 19, 425-442.

May, M., Papazisi, L., Gorton, T. S. \& Geary, S. J. (2006). Identification of fibronectin-binding proteins in Mycoplasma gallisepticum strain R. Infect Immun 74, 1777-1785.

Meng, K. E. \& Pfister, R. M. (1980). Intracellular structures of Mycoplasma pneumoniae revealed after membrane removal. $J$ Bacteriol 144, 390-399.

Mernaugh, G. R., Dallo, S. F., Holt, S. C. \& Baseman, J. B. (1993). Properties of adhering and nonadhering populations of Mycoplasma genitalium. Clin Infect Dis 17 Suppl 1, S69-S78.

Miyata, M. (2005). Gliding motility of mycoplasmas: the mechanism cannot be explained by current biology. In Mycoplasmas: Molecular Biology, Pathogenicity, and Strategies for Control, pp. 137-164. Edited by A. Blanchard \& G. Browning. Norwich, UK: Horizon Bioscience.

Morowitz, H. J. \& Maniloff, J. (1966). Analysis of the life cycle of Mycoplasma gallisepticum. J Bacteriol 91, 1638-1644.

Mudahi-Orenstein, S., Levisohn, S., Yogev, D. \& Geary, S. J. (2003). Cytadherence-deficient mutants of Mycoplasma gallisepticum generated by transposon mutagenesis. Infect Immun 71, 3812-3820.

Papazisi, L., Frasca, S., Jr, Gladd, M., Liao, X., Yogev, D. \& Geary, S. J. (2002). GapA and CrmA coexpression is essential for Mycoplasma gallisepticum cytadherence and virulence. Infect Immun 70, 6839-6845.

Pitcher, D. G., Windsor, D., Windsor, H., Bradbury, J. M., Yavari, C., Jensen, J. S., Ling, C. \& Webster, D. (2005). Mycoplasma amphoriforme sp. nov., isolated from a patient with chronic bronchopneumonia. Int J Syst Evol Microbiol 55, 2589-2594.

Radestock, U. \& Bredt, W. (1977). Motility of Mycoplasma pneumoniae. J Bacteriol 129, 1495-1501.
Razin, S., Yogev, D. \& Naot, Y. (1998). Molecular biology and pathogenicity of mycoplasmas. Microbiol Mol Biol Rev 62, 1094-1156.

Seto, S. \& Miyata, M. (2003). Attachment organelle formation represented by localization of cytadherence proteins and formation of the electron-dense core in wild-type and mutant strains of Mycoplasma pneumoniae. J Bacteriol 185, 1082-1091.

Seto, S., Layh-Schmitt, G., Kenri, T. \& Miyata, M. (2001). Visualization of the attachment organelle and cytadherence proteins of $\mathrm{Myco}$ plasma pneumoniae by immunofluorescence microscopy. J Bacteriol 183, 1621-1630.

Seto, S., Kenri, T., Tomiyama, T. \& Miyata, M. (2005a). Involvement of P1 adhesin in gliding motility of Mycoplasma pneumoniae as revealed by the inhibitory effects of antibody under optimized gliding conditions. J Bacteriol 187, 1875-1877.

Seto, S., Uenoyama, A. \& Miyata, M. (2005b). Identification of a 521-kilodalton protein (Gli521) involved in force generation or force transmission for Mycoplasma mobile gliding. J Bacteriol 187, 3502-3510.

Simecka, J. W. (2005). Immune responses following mycoplasma infection. In Mycoplasmas: Molecular Biology, Pathogenicity, and Strategies for Control, pp. 485-534. Edited by A. Blanchard \& G. Browning. Norwich, UK: Horizon Bioscience.

Stevens, M. K. \& Krause, D. C. (1991). Localization of the Mycoplasma pneumoniae cytadherence-accessory proteins HMW1 and HMW4 in the cytoskeletonlike Triton shell. J Bacteriol 173, 1041-1050.

Tryon, V. V. \& Baseman, J. B. (1992). Pathogenic determinants and mechanisms. In Mycoplasmas: Molecular Biology and Pathogenesis, pp. 457-471. Edited by J. Maniloff, R. N. McElhaney, L. R. Finch \& J. B. Baseman. Washington, DC: American Society for Microbiology.

Tully, J. G., Rose, D. L., Whitcomb, R. F. \& Wenzel, R. P. (1979). Enhanced isolation of Mycoplasma pneumoniae from throat washings with a newly-modified culture medium. J Infect Dis 139, 478-482.

Uenoyama, A. \& Miyata, M. (2005). Identification of a 123-kilodalton protein (Gli123) involved in machinery for gliding motility of Mycoplasma mobile. J Bacteriol 187, 5578-5584.

Waites, K. B. \& Talkington, D. F. (2004). Mycoplasma pneumoniae and its role as a human pathogen. Clin Microbiol Rev 17, 697-728.

Webster, D., Windsor, H., Ling, C., Windsor, D. \& Pitcher, D. (2003). Chronic bronchitis in immunocompromised patients; association with a novel Mycoplasma species. Eur J Clin Microbiol Infect Dis 22, 530-534.

Willby, M. J. \& Krause, D. C. (2002). Characterization of a Mycoplasma pneumoniae hmw3 mutant: implications for attachment organelle assembly. J Bacteriol 184, 3061-3068.

Yogev, D., Browning, G. F. \& Wise, K. S. (2002). Genetic mechanisms of surface variation. In Molecular Biology and Pathogenicity of the Mycoplasmas, pp. 417-444. Edited by S. Razin \& R. Herrmann. New York: Kluwer Academic/Plenum Publishers. 